\title{
EVALUASI KESESUAIAN ERGONOMI ANTARA FASILITAS KAMAR MANDI DENGAN FISIOLOGI DAN ANTROPOMETRI LANSIA
}

\author{
EVALUATION OF ERGONOMY CONFORMITY BETWEEN BATHROOM \\ FACILITIES WITH PHYSIOLOGY AND ANTHROPOMETRY OF ELDERLY
}

\author{
Mohammad Rusda Habib \\ PT. Bangun Sarana Baja \\ E-mail: mohammadrusda313@gmail.com
}

\begin{abstract}
Bathroom was major personal hygiene facilities for elderly in Hargo Dedali Nursing Home Surabaya. Elderly bathroom design need to consider with ergonomic factor for elderly to minimize of falling. The purpose of this study was describing suitability of bathroom facilities ergonomic according physiological and elderly anthropometric factors in the Nursing Home. This study was conducted with cross-sectional design with descriptive analysis approach. Observations and measurements were taken at the place and variables were personal hygiene facilities, physiological, and elderly anthropometric. Data that used were primary data based on observations and interviews and secondary data drawn from the place. The result showed that elderly bathroom ergonomic design were height of closet 42,5 $\pm 2,609 \mathrm{~cm}$; height of bathing tub $68.65 \pm 6.492 \mathrm{~cm}$; height of water cock $90.09 \pm 6.067 \mathrm{~cm}$; volume of water dipper $1000 \mathrm{ml}$; height of hand rail $80.9 \pm 6.067 \mathrm{~cm}$; diameter of handful $4.6 \pm 0.2 \mathrm{~cm}$ at percentile $5 \mathrm{th}$; slope of floor $\geq 4^{\circ}$ with rough floor texture; length of door leaf with handle $16 \mathrm{~cm}$; lighting during the day and the night for more than 100 lux. The conclusion was that not all bathroom facilities at nursing home eligible for elderly. Advice that can be given were the bathroom need adjustment size with ergonomic values obtained and necessary uniformity in design was not only space but also uniformity in size according to the physiological and elderly anthropometric who can access to bathroom independently.
\end{abstract}

Keywords: ergonomics, bathroom, elderly

\section{ABSTRAK}

Kamar mandi merupakan fasilitas utama dalam aktivitas personal hygiene lansia di PW. Hargo Dedali Surabaya. Desain kamar mandi bagi lansia perlu mempertimbangkan faktor ergonomis bagi lansia sebagai salah satu cara meminimalisir kejadian jatuh. Tujuan penelitian ini adalah untuk mendeskripsikan kesesuaian ergonomi fasilitas kamar mandi berdasarkan faktor fisiologi dan antropometri lansia. Penelitian ini merupakan penelitian deskriptif dengan desain penelitian cross sectional. Observasi dan pengukuran dilakukan di panti dengan variabel fasilitas kamar mandi, fisiologi serta antropometri lansia. Data yang digunakan adalah data primer dari observasi dan wawancara serta data sekunder dari dokumen panti. Hasil penelitian menunjukkan bahwa desain ergonomis kamar mandi lansia adalah memiliki ketinggian kloset 42,52 $\pm 2,609 \mathrm{~cm}$; ketinggian bak mandi 68,65 $\pm 6,492 \mathrm{~cm}$; ketinggian kran 90,09 $\pm 6,067 \mathrm{~cm}$; volume gayung $1000 \mathrm{ml}$; ketinggian handrail 80,09 $\pm 6,067 \mathrm{~cm}$; diameter handrail 4,6 $\pm 0,2 \mathrm{~cm}$ persentil 5; kemiringan lantai $\geq 4^{\circ}$ dengan tekstur yang kesat; handel pintu bergagang sepanjang $16 \mathrm{~cm}$; serta cahaya siang dan malam minimal 100 lux. Kesimpulan yang didapat adalah bahwa belum semua fasilitas kamar mandi di panti memenuhi syarat ergonomis kamar mandi lansia. Saran yang dapat diberikan adalah diperlukan penyeragaman kamar mandi tidak hanya dalam desain ruang namun juga penyeragaman dalam ukuran yang sesuai dengan fisiologi dan antropometri lansia.

Kata kunci: ergonomi, kamar mandi, lansia

\section{PENDAHULUAN}

Penuaan merupakan proses fisiologis yang dialami oleh manusia. Bertambahnya usia seseorang, maka kemampuan fisik maupun psikologisnya akan berkurang. Salah satu tanda penuaan dapat ditunjukkan melalui bertambahnya usia. Bustan (2000) dalam Jayanti (2010) menyebutkan bahwa umur kronologis (kalender) manusia dapat digolongkan dalam berbagai masa, yakni masa anak, remaja dan dewasa. Khusus masa dewasa dapat dibagi atas dewasa muda (18-30 tahun), dewasa setengah baya (30-60 tahun), dan masa lanjut usia (lebih dari 60 tahun).

Pada tahun 2010 proporsi penduduk lansia berjumlah sekitar 24 juta dan pada tahun 2020 
diperkirakan jumlah penduduk lansia sekitar 30-40 juta jiwa (Komisi Nasional Lanjut Usia Republik Indonesia, 2010). Gejala menuanya struktur penduduk (aging population) yang terjadi di Indonesia dapat ditunjukkan dengan peningkatan absolut maupun relatif. Kalau pada tahun 1990 jumlahnya hanya sekitar 11 juta, maka pada tahun 2020 jumlah itu diperkirakan akan meningkat menjadi sekitar 29 juta, dengan peningkatan dari $6,3 \%$ menjadi $11,4 \%$ dari total populasi.

Menyikapi hal tersebut, pemerintah Indonesia merasa perlu adanya upaya untuk meningkatkan kesejahteraan sosial golongan lansia, sehingga sejak tahun 2004, pemerintah, melalui presiden mengeluarkan Kepres RI No. 52 tahun 2004 Tentang Komisi Nasional Lanjut Usia yang bertugas membantu presiden dalam mengoordinasikan pelaksanaan upaya peningkatan kesejahteraan sosial lansia serta memberikan saran dan pertimbangan kepada presiden dalam penyusunan kebijakan upaya peningkatan kesejahteraan sosial lansia.

Bermula dari kondisi tersebut, masalah kesehatan lansia merupakan masalah di bidang kesehatan masyarakat yang harus mendapat perhatian karena risiko kecelakaan dapat berdampak bukan hanya pada sisi kesehatan (memerlukan bantuan perawatan medis), tetapi juga aspek sosial dan ekonomi (ketergantungan pada anggota keluarga lain). Kecelakaan yang sering menimpa kalangan lansia ini adalah jatuh, sebagai akibat dari kondisi fisik yang mulai menurun.

Berdasarkan penelitian yang dilakukan oleh Indawati, dkk., (2006) mengenai kejadian jatuh pada lansia di Surabaya, sebanyak 240 lansia yang diklasifikasikan berdasarkan jenis kelaminnya (laki-laki dan perempuan). Sebagian besar lansia (73,3\%) dalam 1 terakhir pada 2006 belum pernah mengalami kejadian jatuh, sedangkan kejadian jatuh paling banyak (5 kali) dialami oleh sedikit lansia, yaitu 1,7\% lansia. Berdasarkan data tersebut terlihat bahwa perempuan lebih banyak mengalami kejadian jatuh dibandingkan laki-laki. Hal ini dapat dilihat pada distribusi lansia yang mengalami jatuh 2 kali atau lebih. Tingginya angka kejadian jatuh pada perempuan dapat menunjukkan bahwa lansia perempuan memiliki kerentanan lebih besar dibandingkan laki-laki, sehingga secara khusus peningkatan kewaspadaan dapat dilakukan pada lansia perempuan.

Berdasarkan hasil survei Indawati, dkk., (2006) dapat diketahui bahwa rata-rata lansia mengalami jatuh tiap tahunnya adalah 0,42 , dimana angka tersebut menunjukkan sedikit lebih rendah dibandingkan hasil penelitian Reuden, dkk., (1996) dalam Andayani (1999), yakni 0,6 insiden jatuh pada masyarakat Amerika terjadi pada kelompok usia $>65$ tahun. Meskipun demikian, perhatian khusus tetap perlu dilakukan oleh keluarga, masyarakat, dan pemerintah.

Kroemer (1994) dalam Indawati, dkk., (2006) menyatakan bahwa sebuah rumah tinggal yang dihuni oleh lansia perlu penyesuaian dan rancangan ulang kamar mandinya. Upaya ini dilakukan dengan pertimbangan bahwa kemampuan gerak motorik lansia telah banyak menurun yang disebabkan oleh penurunan kapasitas sensor motoriknya. Di samping itu, kamar mandi merupakan wilayah paling berbahaya dalam suatu rumah tinggal, maka tempat tersebut perlu mendapat perhatian khusus melalui desain atau rancang bangun yang ergonomis.

Perubahan secara fisiologi yang umumnya dialami lansia diantaranya penurunan kemampuan fisik, penurunan kekuatan otot, penurunan sistem saraf, penurunan koordinasi gerak anggota tubuh serta penurunan ketahanan kardiovaskuler. Sedangkan perubahan antropometri yang sering terjadi adalah bungkuk.

Kemper (1994) dalam Aufa (2011) menyebutkan bahwa kemampuan fisik optimal seseorang dicapai pada usia antara 25-30 tahun, dan kapasitas fisiologis seseorang akan menurun $1 \%$ tiap tahunnya setelah kondisi puncaknya terlampaui, akibatnya banyak aktivitas di masa muda tidak mampu dikerjakan lagi pada masa lansia. Darmojo (2009) dalam Af'idah (2012) menyebutkan bahwa insiden jatuh di rumah perawatan seperti panti werdha 3 kali lebih banyak.

Menurut Arisman (2004) lansia jenis kelamin wanita lebih rentan mengalami kecelakaan dengan persentase $46 \%$ lebih banyak dibanding pria, terutama terjadi di kamar mandi. Hal tersebut menyebabkan pada usia lansia, kamar mandi merupakan wilayah paling berbahaya di dalam suatu rumah tinggal. Berdasarkan uraian tersebut, panti werdha yang dianggap paling rentan terjadinya kecelakaan di kamar mandi adalah panti werdha khusus lansia wanita, seperti pada PW. Hargo Dedali Surabaya.

Pada Maret 2014, tercatat PW. Hargo Dedali Surabaya memiliki 40 penghuni lansia wanita dengan usia antara 61 tahun hingga 111 tahun. Mereka mendapatkan fasilitas kamar mandi sejumlah 16 kamar mandi tersebar pada beberapa bagian panti werdha yang mudah dijangkau serta beberapa kamar 
mandi khusus yang memiliki ukuran lebih luas untuk lansia yang tidak mampu mengakses ke kamar mandi secara mandiri.

Af'idah, dkk., (2012) menyebutkan bahwa pada pra observasi, 5 dari 10 lansia yang tinggal di PW. Hargo Dedali Surabaya pernah mengalami jatuh 1-2 kali dalam 3 bulan terakhir sejak awal tahun. Lalu sebanyak 2 lansia pernah $>3$ kali mengalami jatuh pada rentang waktu yang sama dengan salah satu penyebabnya adalah kondisi kamar mandi yang lantainya licin. Hasil penelitian dalam 3 bulan terakhir menunjukkan bahwa 14 dari 26 responden (54\%) mengalami $>3$ kali jatuh. Meskipun penelitian ini bertujuan untuk mengetahui gambaran risiko jatuh pada lansia, namun identifikasi risiko yang dilakukan peneliti sebatas pada kemampuan berjalan sehingga kiranya perlu dilakukan penelitian lain pada tempat yang rawan bagi lansia untuk terjadi jatuh, seperti pada kamar mandi.

Pengelola harian juga bersikap aktif dalam tindakan meminimalisir kejadian jatuh, seperti menjaga kebersihan kamar mandi serta pendampingan yang lebih intensif pada tiap lansia. Memang setelah dilakukan langkah evaluasi dari pengelola panti kejadian jatuh telah dapat diminimalisir, terbukti dengan tidak adanya kejadian jatuh dalam 3 bulan terakhir terhitung dari Mei 2014, namun terdapat faktor penyebab lain yang masih belum diatasi, diantaranya faktor ergonomi kamar mandi.

Berdasarkan wawancara saat survei pendahuluan kepada pengelola diketahui bahwa saat pembangunan fasilitas kamar mandi khusus lansia proses pembangunannya tidak melalui tahap pengukuran ergonomi fasilitas kamar mandi khusus lansia yang terdiri dari aspek kesesuaian kloset, kondisi lantai, pegangan tangan (handrail), bak mandi (ketinggian bak mandi, kran, dan volume gayung), handel pintu, serta pencahayaan dengan fisiologi dan antropometri lansia.

Suhardi, dkk., (2014) menyebutkan bahwa komponen kamar mandi yang ergonomis bagi lansia adalah tempat duduk, pintu, handrail, kloset duduk, selang pembersih, lampu, shower, rak tempat peralatan mandi, gantungan handuk dan baju, serta komponen lain seperti lantai, ventilasi, dinding, dengan berdasar keluhan lansia. Hal ini berbeda dengan penelitian ini yang berdasarkan komponen kamar mandi secara umum yang merujuk pada penelitian Tarwaka, dkk., (2004) dengan mempertimbangkan fisiologi dan antropometri lansia sebagai batasan masalah penelitian.
Gambaran berbagai risiko penyebab kecelakaan yang berhubungan dengan ergonomi fasilitas kamar mandi bagi lansia di PW. Hargo Dedali Surabaya dapat menjadi dasar penentuan langkah preventif guna mencegah kecelakaan yang mungkin terjadi di kemudian hari oleh penyebab yang telah dikemukakan sebelumnya. Salah satu cara yang dapat dilakukan untuk mengendalikan potensi bahaya yang mungkin terjadi adalah dengan melakukan riset tentang ergonomi fasilitas kamar mandi bagi lansia berdasarkan kesesuaian antara kloset, kondisi lantai, pegangan tangan (handrail), bak mandi (ketinggian bak mandi, kran, dan volume gayung), handel pintu, serta pencahayaan dengan faktor fisiologi dan antropometri lansia.

Riset yang dilakukan diharapkan dapat memberi gambaran kesesuaian ergonomi fasilitas kamar mandi sehingga bermanfaat bagi institusi terkait berupa masukan dalam upaya mencapai panti werdha yang nyaman bagi lansia serta upaya perbaikan dalam pengendalian keselamatan bagi lansia.

\section{METODE}

Menurut cara pengumpulan datanya, penelitian ini termasuk jenis penelitian observasional. Ditinjau dari segi tempatnya, penelitian ini termasuk penelitian lapangan. Dilihat dari metode analisisnya, penelitian ini termasuk penelitian deskriptif. Dari segi waktu rancangan penelitian ini merupakan rancang bangun penelitian cross sectional. Populasi penelitian dalam penelitian ini adalah semua lansia penghuni PW. Hargo Dedali Surabaya yang hingga Maret 2014 tercatat berjumlah 40 orang. Sampel penelitian adalah 23 lansia yang sesuai dengan kriteria inklusi peneliti, yakni lansia yang masih mampu secara mandiri melakukan aktivitas personal hygiene di kamar mandi. Objek penelitian ini adalah ergonomi fasilitas kamar mandi yang diukur berdasarkan ketahanan kardiovaskuler dan antropometri lansia penghuni PW. Hargo Dedali Surabaya.

Penelitian ini dilaksanakan mulai tanggal 1 November 2013 hingga 31 Juli 2014. Proses pengumpulan data dan penelitian dilaksanakan di PW. Hargo Dedali Surabaya, Jawa Timur. Variabel yang diteliti dalam penelitian ini adalah variabel fisiologi lansia yaitu penurunan ketahanan kardiovaskuler, variabel antropometri lansia yaitu berat badan, tinggi tubuh, tinggi bahu, tinggi siku, tinggi knuckle, tinggi popliteal, jarak raih tangan, dan diameter lingkar genggaman, serta 
variabel ergonomi fasilitas kamar mandi lansia yaitu kloset, bak mandi, kondisi lantai, pegangan tangan (handrail), handel pintu, dan pencahayaan. Pengukuran ketahanan kardiovaskuler dilakukan pada aspek denyut nadi dan tekanan darah dengan menggunakan stopwatch, serta pengukuran tekanan darah menggunakan tensimeter.

Pengukuran variabel antropometri lansia menggunakan alat microtoise, mistar dan meteran. Pengukuran variabel ergonomi fasilitas kamar mandi menggunakan waterpass, meteran dan luxmeter. Data disajikan dalam bentuk teks, tabel dan grafik. Data dengan skala pengukuran interval dan rasio untuk masing-masing variabel bisa disajikan dalam bentuk ukuran nilai sentral dan ukuran keragaman. Pada umumnya masing-masing variabel ditampilkan rerata dan standar deviasinya. Penjelasan dari data hasil penelitian dideskripsikan dan dirangkum dengan berbagai variabel yang diidentifikasi sebelumnya.

\section{HASIL}

\section{Ketahanan Kardiovaskuler Lansia di PW. Hargo Dedali Surabaya}

Hasil pemeriksaan dan pengukuran tekanan sistolik responden secara auskultasi reratanya 127,39 $\pm 10,962 \mathrm{mmHg}$ dengan tekanan terendah $110 \mathrm{mmHg}$ dan tekanan tertinggi sebesar $160 \mathrm{mmHg}$. Sehingga, rerata tekanan darah sistolik responden tergolong kategori normal.

Sementara itu, hasil pemeriksaan dan pengukuran tekanan diastolik responden secara auskultasi menunjukkan rerata $76,96 \pm 11,455 \mathrm{mmHg}$ dengan tekanan terendah $60 \mathrm{mmHg}$ dan tekanan tertinggi sebesar $100 \mathrm{mmHg}$. Sehingga, rerata tekanan darah diastolik responden tergolong normal.

Berdasarkan tabel 1, diketahui bahwa sebanyak 23 responden dengan kriteria inklusi lansia yang masih mampu mengakses kamar mandi secara mandiri di PW. Hargo Dedali Surabaya tergolong memiliki beban faal ringan. Rerata denyut beban faal ataupun perfomansi lansia penghuni PW. Hargo Dedali Surabaya adalah 77,17 $\pm 11,464$. Sementara itu untuk hasil pengukuran tekanan darah responden didapatkan rerata persentil 50 yakni 130/80 mmHg yang tergolong kategori pra-hipertensi.

\section{Antropometri Lansia di PW. Hargo Dedali Surabaya}

Berdasarkan hasil pengukuran kepada 23 responden, karakteristik antropometri lansianya adalah sebagai berikut :

Tabel 1. Rerata Denyut Nadi dan Tekanan Darah Lansia di PW. Hargo Dedali Surabaya pada Mei 2014

\begin{tabular}{lcccc}
\hline \multicolumn{1}{c}{ Fisiologi Lansia } & N & Rerata & Standar Deviasi & Rentangan \\
\hline $\begin{array}{l}\text { Denyut nadi per menit } \\
\text { Tekanan darah }\end{array}$ & 23 & 77,17 & 11,464 & $46-100$ \\
$\quad$ & & & \\
a. sistolik (mmHg) & 23 & 127,39 & 10,962 & $110-160$ \\
b. diastolik (mmHg) & 23 & 76,96 & 11,455 & $60-100$ \\
\hline
\end{tabular}

Tabel 2. Rerata Antropometri Lansia di PW. Hagodedali Surabaya pada Mei 2014

\begin{tabular}{lcccc}
\hline \multicolumn{1}{c}{ Antropometri Lansia } & N & Rerata & Standar Deviasi & Rentangan \\
\hline Usia (tahun) & 23 & 77,65 & 11,007 & $61-111$ \\
Berat Badan $(\mathrm{kg})$ & 23 & 43,75 & 7,623 & $34-62$ \\
Tinggi Tubuh $(\mathrm{cm})$ & 23 & 145,17 & 7,050 & $127-158$ \\
Tinggi Bahu $(\mathrm{cm})$ & 23 & 118,65 & 6,492 & $102-131$ \\
Tinggi Siku $(\mathrm{cm})$ & 23 & 90,09 & 6,067 & $75-101$ \\
Tinggi Knuckle $(\mathrm{cm})$ & 23 & 60,74 & 5,956 & $46-69$ \\
Tinggi Popliteal $(\mathrm{cm})$ & 23 & 42,52 & 2,609 & $37-47$ \\
Jarak raih tangan $(\mathrm{cm})$ & 23 & 54,74 & 3,063 & $49-59$ \\
\hline
\end{tabular}


Pada tabel 2, usia dan berat badan tidak termasuk dalam antropometri statis, namun merupakan antropometri untuk komposisi tubuh. Dalam penelitian ini usia dan berat badan menjadi data pendukung dalam pertimbangan kondisi fisiologis lansia. Pada tabel 2, disebutkan bahwa sebaran usia penghuni PW. Hargo Dedali yang menjadi responden dalam penelitian ini memiliki usia termuda adalah 61 tahun, sedangkan usia tertua 111 tahun. Sementara itu, rerata usia responden adalah 77,65 $\pm 11,007$ tahun. Berdasarkan klasifikasi WHO (2000) maka responden tergolong usia lanjut tua $($ old $)$. Sementara itu, berat badan merupakan salah satu indikator status gizi bagi lansia. Berat badan terberat adalah $62 \mathrm{~kg}$, sementara berat badan paling ringan adalah $34 \mathrm{~kg}$. Selanjutnya dapat dihitung reratanya sebesar $43,75 \pm 7,623 \mathrm{~kg}$. Nilai rerata tersebut dapat digunakan untuk menghitung rerata Indeks Massa Tubuh (IMT) responden lansia penghuni PW. Hargo Dedali sebagai indikator status gizi yang memberi informasi penunjang pada kondisi fisiologi lansia, yakni ketahanan kardiovaskuler pada pengukuran denyut nadi dan tekanan darah.

Hasil pengukuran variabel tinggi tubuh pada responden menunjukkan hasil bahwa tinggi tubuh yang paling rendah setinggi $127 \mathrm{~cm}$, sedangkan yang paling tinggi adalah $158 \mathrm{~cm}$. Nilai rerata untuk variabel tinggi tubuh dari 23 responden adalah $145,17 \pm 7,050 \mathrm{~cm}$. Hasil pengukuran variabel tinggi bahu pada responden menunjukkan tinggi bahu terendah adalah setinggi $102 \mathrm{~cm}$, sedangkan yang paling tinggi adalah $131 \mathrm{~cm}$. Nilai rerata untuk variabel tinggi bahu dari 23 responden adalah 118,65 $\pm 6,492 \mathrm{~cm}$.

Hasil pengukuran variabel tinggi siku pada responden menunjukkan tinggi siku terendah adalah setinggi $75 \mathrm{~cm}$, sedangkan yang paling tinggi adalah $101 \mathrm{~cm}$. Nilai rerata untuk variabel tinggi siku dari 23 responden adalah 90,09 $\pm 6,067$ $\mathrm{cm}$. Hasil pengukuran variabel tinggi knuckle pada responden menunjukkan tinggi knuckle terendah adalah setinggi $46 \mathrm{~cm}$, sedangkan yang paling tinggi adalah $69 \mathrm{~cm}$. Nilai rerata untuk variabel tinggi knuckle dari 23 responden adalah 60,74 $\pm 5,956$ $\mathrm{cm}$. Hasil pengukuran variabel tinggi popliteal pada responden menunjukkan tinggi popliteal terendah adalah setinggi $37 \mathrm{~cm}$, sedangkan yang paling tinggi adalah $47 \mathrm{~cm}$. Nilai rerata untuk variabel tinggi popliteal dari 23 responden adalah 42,52 $\pm 2,609 \mathrm{~cm}$. Hasil pengukuran variabel jarak raih tangan pada responden menunjukkan jarak raih tangan terendah adalah setinggi $49 \mathrm{~cm}$, sedangkan yang paling tinggi adalah $59 \mathrm{~cm}$. Nilai rerata untuk variabel jarak raih tangan dari 23 responden adalah $54,74 \pm 3,063 \mathrm{~cm}$.

\section{Kondisi Fasilitas Kamar Mandi Bagi Lansia di PW. Hargo Dedali Surabaya}

Berdasarkan hasil pengukuran ketinggian kloset pada 16 kamar mandi yang digunakan oleh lansia untuk melakukan aktivitas personal hygiene di kamar mandi menunjukkan bahwa semua kloset merupakan kloset duduk dengan ketinggian paling rendah $31 \mathrm{~cm}$ sedangkan yang paling tinggi adalah $40 \mathrm{~cm}$ dengan rerata ketinggian $35,00 \pm 1,966 \mathrm{~cm}$.

Hasil pengukuran ketinggian bak mandi pada 16 kamar mandi yang digunakan oleh lansia untuk melakukan aktivitas personal hygiene di kamar mandi menunjukkan bahwa ketinggian bak mandi paling rendah $75 \mathrm{~cm}$ sedangkan yang paling tinggi adalah $84 \mathrm{~cm}$ dengan rerata ketinggian 79,12 \pm $2,849 \mathrm{~cm}$. Sedangkan hasil pengukuran ketinggian kran pada 16 kamar mandi yang digunakan oleh lansia untuk melakukan aktivitas personal hygiene menunjukkan bahwa ketinggian kran paling rendah $84 \mathrm{~cm}$ sedangkan yang paling tinggi adalah $148 \mathrm{~cm}$ dengan rerata ketinggian 98,69 $\pm 16,406 \mathrm{~cm}$.

Pada pengukuran volume gayung di 15 kamar mandi yang digunakan oleh lansia untuk melakukan aktivitas personal hygiene menunjukkan bahwa volume gayung paling kecil adalah 1000 ml sedangkan yang paling besar adalah $1400 \mathrm{ml}$ dengan rerata 1202,67 $\pm 108,263 \mathrm{ml}$. Saat observasi dilakukan oleh peneliti, ada satu kamar mandi yang tidak terdapat gayung karena gayung rusak dan masih akan diganti serta kamar mandi dalam tahap pra-renovasi sehingga pengukuran hanya dilakukan pada 15 kamar mandi. Sementara hasil pengukuran kemiringan lantai pada 16 kamar mandi yang digunakan oleh lansia untuk melakukan aktivitas personal hygiene menunjukkan bahwa kemiringan lantai paling kecil adalah $2^{\circ}$ sedangkan yang paling besar adalah $20^{\circ}$ dengan rerata $(9,25 \pm 4,933)^{\circ}$. Terdapat 1 kamar mandi yang memiliki kemiringan lantai $<4^{\circ}$ sehingga lantai berisiko terjadi genangan air lebih lama dibandingkan kamar mandi lain yang memiliki kemiringan $\geq 4^{\circ}$ yang digunakan sebagai batas minimal ergonomi kemiringan lantai kamar mandi. Selanjutnya, pada hasil observasi juga menunjukkan bahwa semua kamar mandi, kecuali kamar mandi $M$, memiliki handel pintu berbentuk silinder meskipun memiliki desain pintu yang berbeda-beda. Handel pada kamar mandi $\mathrm{M}$ berbentuk gagang setengah lingkaran dengan keliling 
$13 \mathrm{~cm}$. Selanjutnya, pegangan tangan (handrail) yang menjadi objek penelitian adalah yang berada di depan serta di dalam kamar mandi. Terdapat 6 pegangan tangan (handrail) yang dipasang di sekitar kamar mandi. Pertama, berada pada sekitar kamar mandi B, C, dan D. Kedua, terdapat di sekitar kamar mandi E dan F. Ketiga, terdapat di sekitar kamar mandi G, H, I, dan J. Keempat, terdapat di sekitar kamar mandi $\mathrm{K}$ dan L. Kelima, terdapat di depan kamar mandi M. Keenam, terdapat di sekitar kamar mandi N, O, dan P. Sementara itu, pencahayaan pada setiap kamar mandi menggunakan pencahayaan alami serta buatan yang semuanya tergolong pencahayaan lokal.

\section{Penilaian Ergonomi Fasilitas Kamar Mandi bagi Lansia di PW. Hargo Dedali Surabaya}

Letak setiap kamar mandi berada di sekitar kamar yang dihuni oleh lansia sehingga lansia tidak memerlukan jarak terlalu jauh untuk mengakses kamar mandi jika hendak melakukan aktivitas personal hygiene. Berdasarkan observasi menunjukkan bahwa 16 kamar mandi yang menjadi objek penelitian memiliki komponen fasilitas kamar mandi yang sama. Beberapa hal yang membedakan antarkamar mandi adalah dalam dimensi fisik, seperti ukuran ketinggian kloset, ketinggian bak mandi, ketinggian kran, volume gayung, kemiringan lantai, pegangan tangan (handrail), bentuk handel pintu, serta kondisi pencahayaan pada tiap kamar mandi tersebut. Sehingga sistematika untuk identifikasi kondisi 16 fasilitas kamar mandi secara mendetail dapat diketahui sebagaimana pada Tabel 4.

\section{PEMBAHASAN}

\section{Ketahanan Kardiovaskuler Lansia di PW. Hargo Dedali Surabaya}

Astrand \& Rodahl (1977); Grandjean (1993); Genaidy (1996); dan Konz (1996) dalam Tarwaka, dkk., (2004) menyatakan bahwa umur seseorang berbanding langsung dengan kapasitas fisik sampai batas tertentu dan mencapai puncaknya pada umur 25 tahun. Pada umur 50-60 tahun kekuatan otot menurun sebesar $25 \%$, kemampuan sensorismotoris menurun sebanyak $60 \%$. Selanjutnya kemampuan kerja fisik seseorang yang berumur $>$ 60 tahun tinggal mencapai $50 \%$ dari umur orang yang berumur 25 tahun. Bertambahnya umur akan diikuti penurunan $\mathrm{VO}_{2}$ max, tajam penglihatan, pendengaran, kecepatan membedakan sesuatu, membuat keputusan dan kemampuan mengingat jangka pendek.

Berdasarkan distribusi responden yang paling muda berusia 61 tahun dan yang paling tua berusia 111 tahun, maka diperkirakan rerata kemampuan fisik responden tinggal mencapai $50 \%$ dari umur orang yang berumur 25 tahun.

Sementara itu, sebagaimana telah diketahui kontraksi jantung dikendalikan oleh sistem saraf otonom. Kecepatan denyut jantung dipengaruhi oleh beberapa faktor, yaitu pertama, pressoreflex

Tabel 4. Format Identifikasi Nilai Ergonomi Fasilitas Kamar Mandi di PW. Hargo Dedali

\begin{tabular}{|c|c|c|}
\hline Ergonomi Fasilitas Kamar Mandi & Standar Ergonomis & Kategori \\
\hline Ketinggian kloset & $42,52 \pm 2,609 \mathrm{~cm}$ & \multirow{7}{*}{ Ergonomis/Tidak ergonomis } \\
\hline Ketinggian bak mandi & $\begin{array}{l}\text { per senti } 50 \text { panjang lengan dan jarak } \\
\text { jangkau tangan }(68,65 \pm 6,492 \mathrm{~cm})\end{array}$ & \\
\hline Ketinggian kran & $90,09 \pm 6,067 \mathrm{~cm}$ & \\
\hline Ketinggian gayung & $1000 \mathrm{ml}$ & \\
\hline Kemiringan lantai & $\begin{array}{l}\text { Memiliki kemiringan } \geq 4^{\circ} \text { atau memiliki } \\
\text { kemiringan } 1 \%, \text { artinya setiap } 100 \mathrm{~cm} \\
\text { terjadi kemiringan dengan penurunan } 1 \\
\mathrm{~cm} \text { ke arah saluran air kotor }\end{array}$ & \\
\hline Pegangan tangan (handrail) & Ketinggian $=80,09 \pm 6,067 \mathrm{~cm}$ & \\
\hline Handel pintu & Bergagang dengan panjang $16 \mathrm{~cm}$ & \\
\hline \multicolumn{3}{|l|}{ Pencahayaan } \\
\hline $\begin{array}{l}\text { a. Siang hari (lampu mati dan menyala) } \\
\text { b. Malam hari }\end{array}$ & $100 \operatorname{lux}$ & Ergonomis/Tidak ergonomis \\
\hline
\end{tabular}


jantung yang terletak pada lengkung aorta, carotis sinus, dan bagian proksimal vena cava. Jika daerah ini terangsang, dapat menghambat dan mempercepat kecepatan denyut jantung. Kedua, faktor miscellaneous, misalnya panas, dingin, dan sakit dapat memengaruhi kecepatan denyut jantung. Ketiga, emosi, misalnya perasaan takut akan memperlambat denyut jantung.

Sedangkan faktor-faktor yang memengaruhi mengalirnya darah kembali ke jantung adalah pertama, pengaruh diastolik atrium, diikuti kontraksi atrium yang mengakibatkan pengurasan darah dari atrium sehingga tekanan dalam vena cepat lebih tinggi dari atrium, sehingga darah mengalir dari vena cava ke atrium dexter, kedua, pergerakan pernapasan membantu darah kembali ke jantung. Jika diafragma berkontraksi, maka tekanan dalam rongga perut bertambah, ketiga, kontraksi otot lurik dan gerak valvula semilunaris dari vena. Kontraksi otot lurik akan menekan vena-vena yang halus dalam otot, sehingga tekanan darah naik.

\section{Antropometri Lansia di PW. Hargo Dedali Surabaya}

Wignjosoebroto (1995) dalam Tarwaka, dkk., (2004) menyebutkan bahwa antropometri memiliki arti telaah tentang ukuran badan manusia dan mengupayakan evaluasi dan pembakuan jarak jangkau yang memungkinkan rerata manusia untuk melaksanakan kegiatannya dengan mudah dan gerakan-gerakan yang sederhana. Umumnya manusia berbeda dalam hal bentuk dan ukuran tubuh. Ada beberapa faktor yang akan memengaruhi ukuran tubuh manusia, antara lain pertama, umur, secara umum dimensi tubuh manusia akan tumbuh dan bertambah besar seiring dengan bertambahnya umur yaitu sejak awal kelahirannya sampai dengan umur sekitar 20 tahunan. Kedua, jenis kelamin, pria umumnya memiliki dimensi tubuh yang lebih besar kecuali dada dan pinggul. Ketiga, suku bangsa, yakni dimensi tubuh suku bangsa negara Barat lebih besar daripada dimensi tubuh suku bangsa Timur. Keempat, posisi tubuh, sikap ataupun posisi tubuh akan berpengaruh terhadap ukuran tubuh, oleh karena itu posisi tubuh standar harus diterapkan untuk survei pengukuran.

Pengukuran antropometri dibagi menjadi 2 macam, pertama, penilaian ukuran tubuh, kedua, pengukuran komposisi tubuh. Dalam penelitian ini pengukuran antropometri yang dilakukan adalah pada penilaian ukuran tubuh. Dimensi tubuh manusia yang memengaruhi perancangan interior terdiri dari
2 jenis, yaitu struktural dan fungsional. Dimensi struktural, kadangkala disebut sebagai dimensi statik, mencakup pengukuran bagian-bagian tubuh seperti kepala, batang tubuh dan anggota badan lainnya pada berbagai posisi standar.

Sedangkan dimensi fungsional, yang disebut pula sebagai dimensi dinamik, meliputi pengukuranpengukuran yang diambil pada berbagai posisi kerja atau selama pergerakan yang dibutuhkan oleh suatu pekerjaan. Pada penelitian ini dimensi tubuh yang menjadi objek penelitian adalah dimensi struktural. Sehingga jika dikaitkan dengan penjelasan sebelumnya, pengukuran yang dilakukan adalah penilaian ukuran tubuh pada dimensi struktural.

Data antropometri sangat penting dimiliki oleh perancang fasilitas untuk mendapatkan ukuran yang paling sesuai. Ukuran yang didapatkan harus disesuaikan dengan ukuran tubuhnya dan nyaman bila dimanfaatkan oleh lansia. Untuk mendapatkan ukuran yang sesuai maka dilakukan pengukuran antropometri bagi lansia penghuni PW. Hargo Dedali Surabaya. Antropometri lansia yang menjadi objek penelitian ini meliputi berat badan, tinggi tubuh, tinggi bahu, tinggi siku, tinggi knuckle, tinggi popliteal, jarak raih tangan, serta diameter genggaman tangan.

Pengukuran berat badan tidak secara langsung berpengaruh terhadap rancangan desain ergonomis kamar mandi, namun merupakan faktor pendukung dalam memberikan gambaran keadaan fisiologis lansia di PW. Hargo Dedali Surabaya. Indeks Massa Tubuh (IMT) menunjukkan status gizi secara umum tentang komposisi tubuh. Berfungsi untuk mengukur lansia mengalami kekurangan ataukah kelebihan gizi. Berdasarkan hasil pengukuran didapatkan rerata tinggi responden $145 \mathrm{~cm}$.

Sedangkan rerata berat badan responden adalah $44 \mathrm{~kg}$. Dengan rumus umum IMT $=$ BB $(\mathrm{kg}) / \mathrm{TT}$ $(\mathrm{m})^{2}$, maka hasil yang didapat adalah 20,93 , artinya masih tergolong normal, tidak kurus dan tidak gemuk dengan status gizi baik, sehingga meskipun mengalami penurunan kekuatan secara fisik namun responden tidak mengalami gangguan gizi.

Dengan nilai rerata untuk variabel tinggi tubuh dari 23 responden adalah 145,1 $\pm 7,050$ $\mathrm{cm}$ serta hampir ke semua responden mengalami pembengkokan tulang belakang atau bungkuk maka ukuran tubuh lansia telah terjadi penyusutan ukuran tinggi badannya. Menurut Tilley (1993) serta Samekto \& Pranaka (1999) dalam Tarwaka, dkk., (2004), lebih kurang 5\% dibanding sewaktu berumur 20 tahun. Hal ini disebabkan oleh beberapa 
faktor diantaranya bungkuk dan pembengkokan tulang belakang karena proses penuaan; perubahan tulang rawan dan persendian menjadi tulang dewasa; dan perubahan susunan tulang kerangka pembentuk tubuh karena proses penuaan, dan akibat penyakit lain yang diderita.

Umumnya pengukuran antropometri tinggi bahu dan jarak raih tangan digunakan untuk menentukan lebar sandaran stasiun kerja serta jarak pemasangan mesin dengan stasiun kerja, namun dalam penelitian ini, tinggi bahu dan jarak raih tangan digunakan untuk menentukan salah satu nilai ergonomis fasilitas kamar mandi bagi lansia, yakni ketinggian bak mandi. Memperhatikan panjang lengan dan jarak raih tangan, Manuaba (1998) dalam Tarwaka, dkk., (2004) menyebutkan bahwa tinggi bak mandi dan kedalamannya berdasar ukuran persenti 50 dari jarak tinggi bahu dengan tinggi knuckle. Sehingga setelah diketahui ketinggian bahu, dengan pengurangan per senti 50 dari rerata tinggi bahu responden, yakni $118,65 \pm 6,492 \mathrm{~cm}$, maka didapatkan angka 68,65 \pm 6,492 cm untuk ketinggian bak mandi.

Pada penelitian ini, pengukuran tinggi siku digunakan untuk menentukan ketinggian kran dalam mencapai standar ergonominya. Standar ergonomi ketinggian kran berdasarkan rerata tinggi siku responden, yakni 90,09 \pm 6,067 cm. Sementara itu menurut Grandjean (1993) standar ergonomis ketinggian pegangan tangan (handrail) pada kamar mandi adalah didasarkan pada ketinggian (10-20) cm di bawah siku. Perlu diketahui juga bahwa sebelum pemasangan pegangan tangan (handrail) juga perlu memperhatikan diameternya, yakni berdasarkan rerata diameter genggaman tangan. Rerata diameter ini didapat dari data sekunder pada persentil 5 dengan mempertimbangkan kekuatan fisik lansia, bahwa semakin kecil diameter genggaman tangan (handrail) semakin mudah untuk mendapatkan genggaman yang paling kuat. Standar diameter genggaman tangan didapatkan dari interpolasi data Pheasant (1986), Suma'mur (1989) dan Nurmianto (1991) dalam Nurmianto (2003) yang menjelaskan tentang antropometri telapak tangan orang Indonesia yang dibedakan menurut jenis kelamin. Berdasarkan data tersebut rerata diameter genggaman wanita dewasa, termasuk lansia, sebesar 4,6 $\pm 0,2 \mathrm{~cm}$.

Menurut Manuaba (1998) dalam Tarwaka, dkk., (2004) menyebutkan bahwa ketinggian popliteal digunakan dalam standar ergonomi ketinggian kloset duduk. Pada hasil pengukuran rerata tinggi popliteal responden didapatkan rerata 42,52 $\pm 2,609 \mathrm{~cm}$. Meskipun demikian standar ergonomi ketinggian kloset tidak hanya rerata tersebut, masih terdapat beberapa faktor lain sebagai standar ergonominya. Diantaranya penentuan penggunaan jenis kloset menyesuaikan kondisi lansia, jika lansia mengalami kesulitan berjongkok dan berdiri setelah jongkok dalam waktu tertentu, perlu dipertimbangkan penggunaan kloset duduk.

Selain itu, Bathing (1998) dalam Tarwaka, dkk., (2004) menyebutkan pada fasilitas kloset juga perlu ditambahkan alat untuk memudahkan pembilasan (flusher) setelah buang hajat, seperti alat bidet dan beberapa shower khusus yang tergolong peralatan untuk meningkatkan keamanan pengguna kamar mandi. Namun, perlu diperhatikan juga pemasangan pembilas (flusher) ataupun shower khusus perlu mempertimbangkan kebiasaan lansia, apakah terbiasa menggunakan pembilas ataukah menggunakan gayung air.

\section{Kondisi Fasilitas Kamar Mandi Bagi Lansia di PW. Hargo Dedali Surabaya}

Fasilitas kamar mandi yang menjadi objek penelitian merupakan fasilitas yang merupakan fasilitas primer yang harus ada pada kamar mandi lansia. Kondisi fasilitas kamar mandi yang ada di PW. Hargo Dedali Surabaya telah layak digunakan untuk lansia penghuni, namun dalam pembangunannya belum memperhatikan aspek ergonomi bagi lansia sehingga risiko bahaya yang ada belum dapat diminimalisir. Identifikasi bahaya (Ramli, 2010) adalah upaya yang sistematis dalam mengetahui sifat maupun karakteristik bahaya, agar dapat dilakukan pencegahan-pencegahan dan langkah-langkah pengamanan agar tidak terjadi kecelakaan.

Sementara itu, handel pintu merupakan komponen ergonomi kamar mandi lansia karena kekhawatiran terjadinya lansia yang terkunci di dalam kamar mandi. Berdasarkan penelitian Hadi, dkk., (2001) dalam Tarwaka, dkk., (2004) menunjukkan bahwa dengan mengganti handel pintu menjadi bentuk bergagang, mengakibatkan peningkatan skor sebesar $1,16(25,16 \%)$. Dari $\mathrm{P}_{0}$ adalah 4,61 $\pm 1,26$ dan pada $\mathrm{P}_{1}$ adalah 5,77 $\pm 0,60$. Nilai $p$-value 0,007 , sehingga peningkatan karena intervensi penggantian handel pintu sangat bermakna. Hal ini sesuai dengan penelitian sebelumnya bahwa handel pintu bergagang memudahkan lansia membuka pintu. Dari penelitian tersebut dinyatakan bahwa dengan handel pintu bergagang, kejadian lansia yang 'terkunci' di dalam kamar mandi tidak terjadi lagi. 
Handel pintu bergagang juga memiliki manfaat lain, yaitu berfungsi sebagai pegangan tangan saat lansia masuk dan keluar dari kamar mandi. Pada kondisi handel pintu yang kurang ergonomis bagi lansia juga dapat dilakukan pengendalian risiko terkunci dengan menambahkan bel pada setiap kamar mandi yang terhubung ruang utama panti sehingga dapat segera diketahui jika ada lansia yang sedang terkunci di dalam kamar mandi.

Pencahayaan pada kamar mandi lansia memerlukan cahaya yang tidak terlalu terang den tidak terlalu redup. Berdasarkan Peraturan Menteri Perburuhan No. 7 Tahun 1964 tentang Syarat Kesehatan, Kebersihan serta Penerangan dalam Tempat Kerja pasal 14 ayat $5 \mathrm{j}$ bahwa pencahayaan kakus, tempat mandi dan tempat kencing harus paling sedikit mempunyai kekuatan 100 lux. Pada kasus kamar mandi yang berada di sisi luar deretan kamar mandi serta memungkinkan terkena sinar matahari pagi ataupun sore, seperti pada kamar mandi A, D, F, G, J, dan N, hendaknya perlu di pasang jendela yang cukup untuk menerima cahaya matahari. Jika pantulan cahaya matahari telah memenuhi nilai ergonomis pencahayaan, maka pada kamar mandi tersebut lampu tidak perlu dinyalakan, seperti pada kamar mandi D yang memiliki nilai pencahayaan siang hari sebesar 90 lux saat lampu dimatikan serta 127 lux saat lampu dinyalakan, sehingga pada kamar mandi tersebut hanya perlu menghilangkan benda atau tanaman yang menjadi penghalang di sisi luar kamar mandi dari pantulan cahaya matahari masuk.

\section{Penilaian Ergonomi Fasilitas Kamar Mandi bagi Lansia di PW. Hargo Dedali Surabaya}

Dimensi (ukuran) dari fasilitas kamar mandi ada yang memenuhi serta ada pula yang tidak memenuhi standar persyaratan ergonomis berdasarkan penelitian Tarwaka, dkk., (2004) dan juga Peraturan Menteri Perburuhan No. 7 Tahun 1964 tentang Syarat Kesehatan, Kebersihan serta Penerangan dalam Tempat Kerja. Fasilitas kamar mandi yang memenuhi syarat ergonomi dari 16 kamar mandi yang menjadi objek penelitian antara lain, Pertama, ketinggian kloset. Berdasarkan observasi menunjukkan bahwa ketinggian kloset yang sudah ergonomis hanya pada kamar mandi A. Kedua, ketinggian bak mandi. Hasil observasi menunjukkan bahwa tidak ada kamar mandi yang sudah memenuhi syarat ergonomis ketinggian bak mandi berdasarkan hasil pengukuran antropometri responden. Ketiga, ketinggian kran. Hasil observasi menunjukkan bahwa ketinggian kran yang sudah ergonomis adalah pada kamar mandi B, C, D, E, G, H, I, J, dan K. Keempat, volume gayung. Berdasarkan observasi menunjukkan bahwa volume gayung yang sudah ergonomis hanya pada kamar mandi G. Kelima, kemiringan lantai. Hasil observasi menunjukkan bahwa kemiringan lantai yang sudah ergonomis adalah pada kamar mandi A, C, F, G, N, O, dan P. Sementara itu kondisi fisik lantai pada 16 kamar mandi yang digunakan responden telah memiliki tekstur yang kasar dan bercorak sehingga dapat meminimalisir terjadinya kejadian terpeleset.

Keenam, ketinggian pegangan tangan (handrail). Sebagaimana hasil observasi menunjukkan bahwa pegangan tangan (handrail) hanya terdapat di luar kamar mandi dengan ukuran rerata ketinggian 84,83 $\pm 3,312 \mathrm{~cm}$ dari 6 titik pemasangan pegangan tangan (handrail) di sekitar 16 kamar mandi. Sedangkan dari 16 kamar mandi sama sekali tidak terdapat pegangan tangan (handrail) di desain interiornya.

Ketujuh, handel pintu. Handel pintu yang ergonomis bagi lansia sebagaimana penelitian Nurmianto (2003) dalam Tarwaka, dkk., (2004) adalah handel pintu bergagang yang panjangnya $16 \mathrm{~cm}$ dengan perincian sebagaimana rerata lebar telapak tangan perempuan Indonesia, yakni $10 \mathrm{~cm}$ serta estimasi lebihnya masing-masing $3 \mathrm{~cm}$ di bagian kanan dan kiri telapak tangan. Menilik hal tersebut semua handel pintu kamar mandi lansia yang menjadi objek penelitian tidak ada yang sesuai karena semua menggunakan handel pintu silinder dengan kondisi beberapa handel pintu telah rusak.

Kedelapan, pencahayaan siang hari. Berdasarkan Peraturan Menteri Perburuhan No. 7 tahun 1964 Tentang Syarat Kesehatan, Kebersihan serta Penerangan dalam Tempat Kerja pasal 14 ayat $5 \mathrm{j}$, hanya terdapat 1 kamar mandi dengan pencahayaan siang hari yang sesuai ketentuan minimal 100 lux, yakni kamar mandi D dengan pencahayaan siang hari sebesar 127 lux. Sementara pada pencahayaan malam hari, 16 kamar mandi memiliki pencahayaan kurang dari 100 lux.

Fasilitas kamar mandi yang belum memenuhi syarat ergonomi antara lain, Pertama, kamar mandi yang ketinggian klosetnya belum memenuhi syarat ergonominya sebanyak 15 , yakni kecuali kamar mandi A, antara lain kamar mandi B, C, D, E, F, G, H, I, J, K, L, M, N, O, dan P. Kedua, variabel ketinggian bak mandi semua kamar mandi belum memenuhi standar ergonomisnya. Ketiga, 
ketinggian kran, terdapat sebanyak 7 kamar mandi yang belum memiliki ketinggian kran yang sesuai, antara lain kamar mandi A, F, L, M, N, O, dan P.

Keempat, variabel volume gayung, terdapat sebanyak 15 kamar mandi, kecuali kamar mandi G memiliki volume gayung yang masih lebih besar dari standar ergonomisnya. Kelima, ketinggian pegangan tangan (handrail) di dalam kamar mandi. Semua kamar mandi belum memiliki pegangan tangan (handrail) pada desain interiornya. Keenam, variabel kemiringan lantai, terdapat sebanyak 10 kamar mandi yang belum memenuhi standar ergonominya pada kemiringan $\geq 4^{\circ}$, yakni kamar mandi $\mathrm{B}, \mathrm{C}$, D, E, H, I, J, K, L, dan M. Ketujuh, Handel pintu. Semua kamar mandi tidak memiliki handel pintu yang memenuhi syarat ergonomisnya, kecuali kamar mandi M. Kedelapan, Pencahayaan siang hari semua belum memenuhi syarat, kecuali kamar mandi D. Kesembilan, pencahayaan malam hari semua kamar mandi belum memenuhi syarat ergonomisnya.

Karakteristik gangguan kesehatan pada kondisi kurang ergonomis cenderung pada gangguan atau cedera tingkat rendah yang muncul lambat laun setelah proses salah yang lama dan berulang ketika melakukan aktivitas personal hygiene di kamar mandi. Walaupun muncul secara evolusif, hasil akhir tetap sama dapat berupa gangguan kesehatan yang serius seperti gangguan saraf, gangguan penglihatan, cidera otot dan pergelangan, mengalami stress, dan sebagainya (Pujadi, 2008).

\section{SIMPULAN}

Dari hasil penelitian yang telah dilakukan didapatkan kesimpulan bahwa belum semua fasilitas kamar mandi di PW. Hargo Dedali memenuhi syarat ergonomis kamar mandi lansia. Saran yang dapat diberikan adalah pada periode pembangunan dan perbaikan kamar mandi yang akan datang perlu penyesuaian dimensi (ukuran) dengan nilai ergonomis yang didapat serta diperlukan penyeragaman tidak hanya dalam desain ruang namun juga penyeragaman dalam ukuran yang sesuai dengan fisiologi dan antropometri lansia yang dapat mengakses ke kamar mandi secara mandiri. Selanjutnya saran yang dapat diberikan untuk penelitian berikutnya adalah desain ergonomis kamar mandi lansia berdasarkan faktor psikologisnya.

\section{DAFTAR PUSTAKA}

Af'idah, Frida Sianita N.A., Dewi, Yulis Setya, Hadhisuyatmana, Setho. 2012. Studi Risiko Jatuh Melalui Pemeriksaan Dynamic Gait Index (DGI) pada Lansia di Panti Werdha Hargo Dedali Surabaya. Jurnal Unair: 2, 4-6.

Andayani.1999. Buku Ajar Geriatri. Balai Penerbit FKUI.

Arisman. 2004. Gizi dalam Daur Kehidupan: Buku Ajar Ilmu Gizi. Jakarta: EGC.

Aufa, M. In'amul. 2011. Faktor yang Berhubungan dengan Keluhan Muskuloskeletal pada Pekerja Pemecah Batu Tradisional (Studi di Bantaran Sungai Kalisetail Kecamatan Genteng Banyuwangi). Skripsi. Surabaya. Universitas Airlangga.

Indawati, Rachmah M., Sunarnatalina, Sulistyowati, Muji. 2006. Analisis Faktor untuk Mengetahui Sikap Berisiko Kecelakaan pada Lanjut Usia (Lansia). Laporan Penelitian. Surabaya. Universitas Airlangga.

Jayanti, Septi Dwi. 2010. Perbedaan Pola Penggunaan Suplemen pada Lansia yang Tinggal di Panti dan di Luar Panti (Studi di Panti Hargo Dedali dan Wilayah Kerja Puskesmas Menur). Skripsi. Surabaya. Universitas Airlangga: 8-9.

Komisi Nasional Lanjut Usia/Profil Penduduk Lanjut Usia 2009. http://www.komnaslansia.go.id/ d0 wnloads/profil/Profil_Penduduk_Lanjut Usia_2009.pdf (Sitasi 4 November 2013).

Peraturan Menteri Perburuhan No. 7 Tahun 1964 tentang Syarat Kesehatan, Kebersihan serta Penerangan dalam Tempat Kerja.

Presiden RI/Kepres RI No. 52 Tahun 2004 tentang Komisi Nasional Lanjut Usia. http://www. komnaslansia.go.id/d0 wnloads/kepres_no_52.pdf (Sitasi 21 November 2013).

Ramli, Soehatman. 2010. Sistem Manajemen Keselamatan dan Kesehatan Kerja. Jakarta: PT. Dian Rakyat.

Suhardi, Bambang., Utomo, Brian Pujo., Rochman, Taufiq. 2014. Desain Kamar Mandi untuk Orang Lanjut Usia (Studi Kasus Panti Werdha Dharma Bhakti). Jurnal. Surakarta. Universitas Sebelas Maret.

Tarwaka, Solichul H.A. Bakri, Lilik Sudiajeng. 2004. Ergonomi - untuk Keselamatan, Kesehatan Kerja \& Produktivitas. Jakarta: Penerbit Buku Kedokteran. 